\title{
The Manufacture and Distribution of Handguns As an Abnormally Dangerous Activity
}

Each year the use of handguns leads to the injuries and deaths of thousands of individuals as a result of accidents, suicides, and homicides. ${ }^{1}$ The court system is left with the question of who will ultimately bear the costs of the injuries, since legislatures have generally not addressed the problem. The answer need not be constrained by one's beliefs about the desirability of handguns. The inquiry is a legal one, possible without degeneration into shrill rhetoric about the role of handguns in society.

Some injuries and deaths resulting from handguns pose no unusual legal questions. For example, where a handgun manufacturer either is negligent in the manufacture or distribution of a handgun or produces a defective handgun, personal injuries or deaths that result will lead to manufacturer's liability under either negligence or strict products liability principles. However, many (if not most) handgun injuries do not result from the manufacturer's negligence or from a defect in the product. It is this class of injuries-those resulting from the use of a properly functioning handgun-that presents the most difficult legal questions, questions made particularly troublesome by the fact that handgun manufacturers inject into the stream of commerce products intended to facilitate the infliction of grave personal injury. ${ }^{2}$ In this respect, the question of

1 Accidental handgun deaths occur at a rate of about 200 annually. See David T. Hardy, Product Liability and Weapons Manufacture, 20 Wake Forest L. Rev. 541, 551 (1984). It is not known how many of these accidental deaths would be compensated under the current application of existing legal rules. Handgun homicides made up about 50 percent of all murders from 1978 to 1981, when murders averaged about 20,000 annually. See Statistical Abstract of the United States 171 (1985) (table 286). Handgun suicides, while a significant problem, are not within the scope of the rule advocated by this comment. See note 151 and accompanying text below. The focus of this comment is on the approximately 10,000 deaths and injuries that are caused by the criminal and accidental use of handguns every year.

2 Some discussions about manufacturers' liability for handgun injuries distinguish inexpensive, small-caliber handguns ("Saturday Night Specials") from other handguns. It is questionable whether one type of handgun is more frequently used as a weapon in crime than another. See Steven Brill, Firearm Abuse: A Research and Policy Report 49 (1977). Furthermore, for the reasons stated in note 106 below, the analysis of this comment applies to all handguns and not just to Saturday Night Specials. 
the liability of handgun manufacturers differs from the question of the liability of manufacturers of other commercial products.

One approach to holding manufacturers liable for the injuries caused by their handguns is to classify a handgun as somehow defective, even if it is mechanically perfect. ${ }^{3}$ This approach has generally failed in the courts, ${ }^{4}$ and commentators have agreed that the law of products liability is inappropriate to deal with injuries caused by well-made handguns. ${ }^{5}$

Another strict liability approach attempts to classify the manufacture and distribution of handguns $s^{6}$ itself as an ultrahazardous or abnormally dangerous activity. The courts have greeted this approach with little enthusiasm, however, and no commentator has endorsed it. But the ultrahazardous activity doctrine, when properly understood in its economic and historical contexts, offers a compelling basis for holding handgun manufacturers and distributors strictly liable for many personal injuries caused by handguns.

This comment begins with an economic analysis of the application of strict liability to handgun manufacturers and distributors. It demonstrates the superiority of the strict liability rule over a negligence standard for maximizing social welfare in certain types of activities, including an abnormally dangerous activity such as handgun manufacture and distribution. The comment next discusses the historical development of the abnormally dangerous activities doctrine and its current formulation. The discussion shows that the manufacture and distribution of handguns is properly classified as abnormally dangerous and that placing liability on the manufacturer and distributor is the better of two imperfect alter-

${ }^{3}$ See, e.g., Patterson v. Gesellschaft, 608 F.Supp. 1206 (N.D. Tex. 1985).

- See id. But consider Kelley v. R.G. Industries, Inc., 304 Md. 124, 497 A.2d 1143 (1985) (holding manufacturers strictly liable for the sale of Saturday Night Specials, not under products liability, but under a new niche of strict liability).

- See, e.g., Note, Handguns and Products Liability, 97 Harv. L. Rev. 1912 (1984). But contrast Comment, A Shot at Stricter Controls: Strict Liability for Gun Manufacturers, 15 Pac. L. J. 171 (1983) (no significant barrier to application of products liability doctrines to manufacturers of snubnose handguns).

- The phrase "manufacture and distribution of handguns" refers to the original manufacture and the subsequent distribution of handguns to consumers by that manufacturer or downstream entities; it is treated throughout this comment as a collective noun. Manufacturing alone is too narrow since without the subsequent distribution of handguns no handguns ever would enter the public domain. In 1979, sixteen manufacturers accounted for 96.5 percent of all nonmilitary U.S. handgun production. Pete Shields, Guns Don't Die-People Do 41 (1981) (citing data of Bureau of Alcohol, Tobacco, and Firearms). The federal government had approximately 158,000 licensed dealers in wholesale and retail firearms in 1981 . Id. at 182 (citing data of Bureau of Alcohol, Tobacco, and Firearms). It is unclear how many of these dealers traded in handguns. 
natives. Finally, the comment distinguishes the manufacture and distribution of handguns from the manufacture and distribution of other consumer products and suggests solutions to potential problems in implementing strict liability against handgun manufacturers and distributors.

\section{The Economics of Handgun InJuRIes}

This section analyzes the costs and benefits of applying strict liability against manufacturers and distributors of handguns. It first examines the activities for which strict liability is a more efficient rule than negligence and then demonstrates that the manufacture and distribution of handguns is among these activities.

\section{A. The Rule of Strict Liability}

Liability rules fall into three general categories: negligence, strict liability, and no liability. ${ }^{7}$ The common law choice of one of these rules was often determined by the judges' individualized perceptions of justice. Because the concept of "justice" is subjective and ethereal, modern courts and commentators have looked for alternative justifications for choosing a particular liability rule. Economic analysis has surfaced as a leading methodology informing the choice of liability rules. ${ }^{8}$

The costs of accidents remain on the victims unless shifted by a liability rule. Thus, in the absence of such a rule, the costs of accidents are not included in the injurers' decision-making criteria. Imposing liability internalizes those costs-forces injurers to consider them-and thus prima facie increases efficiency. However, these external costs are not the only factors that should be focused upon in assessments of economic efficiency. Efficiency requires

I Intentional torts can be seen as embodying a fourth liability rule, requiring a unique standard of culpable conduct (intent) before liability will ensue. The economic literature, however, does not treat this rule independently, probably because liability for intentional torts is generally subsumed within negligence liability. The only instance in which a defendant would be liable for an intentional tort but not for negligence would be when the intentional commission of a tortious act was reasonable-presumably a small and relatively unimportant category of cases. Consideration of the law of intentional torts as an independent liability rule is hereafter omitted from the discussion.

- Leading judicial examples include United States v. Carroll Towing Co., 159 F.2d 169 (2d Cir. 1947) (applying negligence formula through weighing expected costs of accident against costs of avoidance); Escola v. Coca-Cola Bottling Co. of Fresno, 24 Cal.2d 453, 150 P.2d 436 (1944) (choosing strict liability rather than negligence on grounds of optimal risk allocation). Leading academic discussions include Steven Shavell, Strict Liability Versus Negligence, 9 J. Legal Stud. 1 (1980); John Prather Brown, Toward an Economic Theory of Liability, 2 J. Legal Stud. 323 (1973). 
maximizing the net benefits of joint activities. ${ }^{\circ}$ Unless the conduct of the victim is wholly independent of the function defining frequency and severity of the accident, the conduct of the victim should also be taken into account in fashioning liability rules.

The conduct of injurers and victims breaks down into two components: the standard of care and the level of activity. ${ }^{10} \mathrm{Be}$ cause of the difficulty of ascertaining optimal activity levels in individual cases, judges in applying a given liability rule in a case generally only consider the standard of care. ${ }^{11}$ But when the question is not whether there is liability under a given rule, but rather which liability rule should apply, the failure to consider activity levels may become excessively costly.

The level of activity is, essentially, the frequency with which given parties engage in conduct that creates a risk of harm. The concept applies equally to the injured, to the injurer, and to any other party who could be said to constitute a "but for" cause of the threatened accident. Consider, for example, the two-party paradigm of a person who decides to drive to the store for a candy bar and a pedestrian who crosses the road on his way to a movie. Assume that even though both parties exercise due care, the driver hits the pedestrian. Given that the accident could not have been prevented with reasonable care, who should bear the cost of the accident? Should the driver have foregone her candy bar, or should the pedestrian have missed the movie-that is, which actor should have curtailed her activity in this marginal case? The short answer is: the person whose conduct would have led to the greatest reduction in overall costs.

The problem is that no matter which liability rule obtains, one of the parties will engage in too much activity. For example, if negligence is the rule, the pedestrian will bear the loss in our hypothetical accident. Thus, the driver will not consider the costs of a nonnegligent accident when deciding to drive to the candy store, because those costs are external to her. As a result, even if she does not want the candy very much, she will take the trip if the benefit she receives from the candy outweighs her costs in time, gasoline, and the price of the candy. But if she had to consider the costs of

- See generally R. H. Coase, The Problem of Social Cost, 3 J. L. \& Econ. 1 (1960).

${ }_{10}$ For general background, see Shavell, $9 \mathrm{~J}$. Legal Stud. 1 (cited in note 8).

11 Modification of the negligence rule to include explicit recognition of activity levels would solve this problem. It is questionable, however, whether courts are equipped to make effective judgments about activity levels. See Comment, A Time-Dependent Model of Products Liability, 53 U. Chi. L. Rev. 209, 218-20 (1986). 
the accident, in the marginal case she might stay at home and have cookies instead.

On the other hand, if strict liability with a defense of contributory negligence is the prevailing rule, the driver bears the costs of the nonnegligent accident, and those costs will be external to the injured pedestrian to the extent the liability rule compensates him for the injury. The pedestrian thus will walk to the movie, even if he has already seen it, when if he had to bear the cost of a nonnegligent accident, he might (in the marginal case) stay home and watch T.V.

The optimal activity level, then, is the one at which each actor considers the cost of nonnegligent accidents in deciding whether to engage in conduct that may be a but-for cause of an accident. This internalization of costs is the function of liability rules. The choice between the strict liability rule with contributory negligence (sometimes called the modified strict liability rule) and the negligence rule, from the standpoint of efficiency, will depend on whether it is more effective to control the injurer's activity or the victim's activity. ${ }^{12}$

Neither rule leads to a generally efficient result, because neither considers activity levels; each examines only the standard of care. ${ }^{13}$ Under negligence, all levels of the injurer's nonnegligent activity escape liability, but only those levels that produce benefits greater than the increased accident costs they engender are efficient. Similarly, under the modified strict liability rule, victims' nonnegligent activity levels will continue even when the additional activity reduces social welfare. The flaw in both regimes derives from the failure of courts to account for the declining marginal social utility of an activity.

Nonetheless, both rules are superior to no liability or to strict liability without the defense; ${ }^{14}$ and in most cases one rule will be better than the other. Strict liability with the defense of contributory negligence is superior to the negligence rule if injurer activity contributes more to social loss than does victim activity. ${ }^{15}$ Conversely, if victim activity contributes more to social loss, the negligence rule is appropriate.

According to both Richard Posner and Steven Shavell, the

12 See Shavell, 9 J. Legal Stud. at 19 (cited in note 8).

${ }^{13}$ Id. at 19-25. See also Richard A. Posner, Economic Analysis of Law 139-40 (2d ed. 1977).

14 Shavell, 9 J. Legal Stud. at 19 (cited in note 8) (Proposition 4).

13 See Comment, 53 U. Chi. L. Rev. at 218-20 (cited in note 11). 
above analysis helps explain the rule of strict liability in certain areas of the tort law, among them cases of ultrahazardous activity. ${ }^{16}$ Given that a choice between the negligence rule or the modified strict liability rule is one between the lesser of two evils, ${ }^{17}$ the optimal rule depends on the positions of the victims and injurers. The less significant the effect of internalization of accident costs on victim activity levels and the less significant the effect of victim activity levels on accident costs, the greater the efficiency of the strict liability rule. ${ }^{18}$

In the traditional categories of "ultrahazardous activities," victims' activities are often "entirely routine in nature, part of what it is to carry on a normal life."18 In contrast, an injurer's ultrahazardous activity usually possesses distinctive aspects that allow the law to single out such activity. ${ }^{20}$ Victim conduct-just plain living-would not change much as a result of liability, while injurer conduct-unique and unusual-would respond to liability. Posner argues that in cases of ultrahazardous activities, potential victims are not in a good position to make adjustments to their behavior that might eventually reduce or eliminate the risk of injury. ${ }^{21}$ For this reason, imposing strict liability on the injurer will control such activity better than, and will create greater gains in social welfare than, the negligence rule. The economic model, then, justifies the strict liability rule with contributory negligence for cases of ultrahazardous activities. This is approximately the common law rule. ${ }^{22}$

${ }^{18}$ Posner, Economic Analysis at 140-41 (cited in note 13); Shavell, 9 J. Legal Stud. at 24-25 (cited in note 8).

17 Shavell, 9 J. Legal Stud. at 19 (cited in note 8).

${ }^{18}$ For certain types of ultrahazardous activities, such as creating a sonic boom, victims' conduct will have virtually no bearing on accident costs. In such a case strict liability is unambiguously the most efficient rule. See id. at 2-3. Other ultrahazardous activities, such as trucking explosives, reflect victims' activity levels to the extent that the more automobiles on the road when the miscarriage occurs, the greater the cost of the accident. The negligence rule would place the loss on these victims without necessarily deterring their future automobile trips generally. The strict liability rule, on the other hand, forces even the nonnegligent trucker to consider the expected accident cost of each trip, assuring that the trip will be made only if the benefits exceed the total social cost.

18 Id. at 24.

20 Id.

21 Posner, Economic Analysis at 140-41 (cited in note 13).

22 The abnormally dangerous activities doctrine as formulated by the Restatement (Second) of Torts bars recovery for plaintiffs where there is either assumption of risk or contributory negligence when the risk is known; contributory negligence with respect to failure to discover the risk is not a defense. Restatement (Second) of Torts $\S \S 523-24, \S 524$ comment a (1977). A plaintiff's unusual sensitivity to an otherwise abnormally dangerous activity will also bar recovery under the rule. Id. § 524A. 


\section{B. Strict Liability Against Handgun Manufacturers and Distributors}

As noted at the outset, current liability rules compensate victims for injuries resulting from the negligence of a handgun manufacturer or distributor or from a defect in the handgun itself. For all other injuries and deaths, victims or their estates cannot recover from handgun manufacturers or distributors. This section argues that the current negligence regime for the manufacture and distribution of handguns is inappropriate. Using the economic analysis concerning the optimal control of activity levels, ${ }^{23}$ it concludes that strict liability is the proper rule, since it is the manufacturers' and distributors' activity levels that are most costly if uncontrolled.

The noncriminal activities of handgun victims are essentially those of everyday living. ${ }^{24}$ To refrain from one activity necessarily requires the participation in another with similar risk. While the exact degree of risk of handgun injury may change as the victim moves from activity to activity, the change in risk is likely to be small, and the victim probably cannot significantly reduce the risk at reasonable cost. To be sure, the victim could quit his job or barricade himself, alone, in his house. But such safety measures would, at a systematic level, prove more costly than the injuries they prevented and so would be inefficient. In other words, the desire to engage in employment and (arguably) the desire to live in a home that is not barricaded are relatively inelastic. If such activities are made to bear the cost of handgun injuries, the activities and thus the injury costs will continue at nearly the same level, or victims will substitute alternative activities with substantially the same risk of handgun injury. Moreover, as a matter of policy, society might not wish to do anything to deter these normal, everyday activities.

Even if victim behavior did change dramatically, it probably would not create costs comparable to those currently created by manufacturers' and distributors' behavior. Nonnegligent victim ac-

${ }^{2 s}$ In applying this analysis, one must consider, for both victim and injurer, the likely activity level of both parties under a given rule and the statistical effect those activity levels should have on accident costs.

${ }^{24}$ Victims who use guns legally in the course of their livelihoods, such as policemen and security guards, are a special class. Their decisions to enter such a field, and decisions made during the course of their work, naturally heighten the risk of handgun injury. The positions of these victims are analytically similar to those of handgun owners, discussed below at notes 144-47 and accompanying text. This class of victims would not recover under the proposed liability rule. 
tivity, even viewed cumulatively, cannot possibly have a correlation to shooting injuries approaching that of the manufacture and distribution of certain kinds of handguns (as a proportion of the value of the activity). Marginal victim activity would be much less wasteful than is marginal injurer activity.

Yet it is unlikely that victims would dramatically increase their participation in risky activities if they no longer had to bear the cost of nonnegligent handgun injury. This is so not only because of the nature of victim conduct, but also because a legal remedy does not eliminate a victim's incentive to avoid a handgun accident. Few people view a money judgment as perfect compensation for grave physical injury or death. Furthermore, at some point victim conduct becomes contributorily negligent and bars recovery.

Manufacturers, on the other hand, are likely to respond more directly and substantially to facing liability than victims respond to the presence or absence of a legal remedy. Their marginal cost curves shift upward in an amount equal to the cost of handgun accidents at each level of production (activity). Under a strict liability regime, manufacturers will face a higher marginal cost curve and will correspondingly charge higher prices. Assuming any nonzero price elasticity of demand for handguns, consumers will buy fewer handguns, since some who would have bought a handgun before will not find it worth the extra price. To the extent that the risk of uncompensated injury to a third-party constitutes a real cost of the handgun in the consumer's hands, the consumer's decision not to pay this cost in the price is welfare maximizing since it reflects the fact that the consumer's benefit from having the gun is less than society's benefit from his not having it.

Of course, handguns are only one category of firearms in general, and the handgun market itself is fairly differentiated: some owners use handguns for legitimate, low-risk purposes. At the point of sale or before, the manufacturer or salesperson may not be able to tell which buyer will use the handgun to inflict otherwise uncompensated injury on a victim (and consequently inflict liability on the manufacturer) and which buyer will use the handgun for purely legitimate purposes. Unless the market is sufficiently differentiated or alternative pricing mechanisms exist, the manufacturer must spread the risk evenly across the product, charging the average cost of liability to each gun. The inevitable result is that some customers who would have used the gun for legitimate purposes will be deterred from purchase by the higher price. These customers miss out on the benefit of gun ownership, and yet their forbear- 
ance saves no uncompensated accident costs. The result is social loss.

On the other hand, some people deterred from handgun purchases would have inflicted massive uncompensated injury; keeping guns from them creates social gain. Thus, whether or not discouraging handgun purchases will create net social gain depends on how accurately the manufacturer can estimate the actual risks of a sale and what other options are available to "priced-out" consumers.

There are reasons, however, to think that the handgun market is sufficiently differentiated so that prices and hence activity levels will eventually reflect the risks associated with the sale of each gun of a certain type. Handguns come in a variety of designs, in many degrees of quality, and at many prices. Some are more appropriate for sport, some for military or police work, and some appear best suited for criminal use ${ }^{25}$ or for self-defense. Moreover, handguns are sold in a number of markets, such as to the military, the police, private users, and dealerships.

The more injuries a particular type of handgun causes, the more a strict liability rule will increase the price and reduce the quantity demanded of that type of gun. Consequently, the portion of the manufacturer's production that is least efficient will be affected most; the guns that cause the most net loss will show the sharpest declines in quantities sold once social cost is included in the price. Likewise, handguns that are safer, or because of type, price, or selective marketing are rarely used in a way that externalizes the cost of injuries, would experience a smaller increase in price and a smaller decline in sales. No doubt, substitution among handgun models would occur, but manufacturers (and their insurers) can anticipate this and change prices and production levels accordingly.

Furthermore, the manufacturer is not bound to take the market as he finds it; he may reduce the risk of handgun injuries by adjusting his designs and marketing practices. For example, he may reduce the number of accidental injuries caused by his product by imposing a minimum age for purchase or by requiring NRA training, and he may reduce the number of intentionally inflicted injuries by extending the barrel of his handguns to make them less concealable or by refusing sales to identifiably high-risk people. Strict liability increases his incentives to do so. In short, under

${ }^{26}$ See notes $105-07$ and accompanying text below. 
strict liability a large amount of inefficient handgun production activity would be averted, producing net social gain.

To be sure, manufacturers' liability is not the exclusive means for internalizing costs more fully. The purchaser or the user of the handgun could also be subjected to strict liability. Then, when the consumer decided to buy or use a gun, the expected cost of liability-which under strict liability is all accident costs caused by the handgun-would become part of his cost of purchase or use. The higher effective cost of the handgun to purchasers and users would lead to lower consumption, that is, reduced injurer activity levels. ${ }^{26}$ Even if the purchaser and user were not the same person, the liability rule would limit the market to an efficient number of handguns.

Thus, strict liability against purchasers and users likely would be more efficient than the current system, under which they are liable for only intentionally or negligently caused injuries. Strict liability against purchasers and users might produce even greater efficiency gains than strict liability against manufacturers and distributors, since the former have more control over and information about the risk of handgun injuries.

However, strict liability against purchasers and users breaks down in many cases for two reasons. First, when an injury occurs, it may be impossible to identify the purchaser or user, particularly if he is a criminal who fled the scene of the crime. Second, even when identification is possible, the purchaser or user is often judgment proof. ${ }^{27}$ This poses a "moral hazard" problem: even if consumers could accurately assess the frequency and severity of handgun injuries, they would not consider the full expected social cost in their purchase decisions since they would not expect to pay it. On the other hand, imposing strict liability on manufacturers and distributors would present no insurmountable problems of identifi-

${ }^{26}$ A retail tax would achieve the same result on the demand side as strict manufacturers' liability. Congress has apparently adopted this (partial) solution to the problem of externalities in alcohol consumption. Only if this handgun tax were high enough and were used to compensate victims (and not just to increase general revenues) would the result be equivalent to strict manufacturers' liability. Furthermore, such a solution requires explicit legislation, whereas the solution advocated by this comment applies existing legal doctrine.

${ }^{27}$ See Decker v. Gibson Products Co. of Albany, Inc., 505 F.Supp. 34, 37 (M.D. Ga. 1980), rev'd, 679 F.2d 212 (11th Cir. 1982). A rule requiring handgun purchasers and users to carry insurance could ameliorate this problem. Insurance companies may be even better able to monitor injurer behavior than manufacturers and distributors. But criminals are unlikely to acquire insurance. In any case, mandatory insurance would require legislation and would be difficult to enforce at the individual level. 
cation or financial responsibility. ${ }^{28}$ Accordingly, strict liability against handgun manufacturers and distributors is optimal in limiting handgun purchases to an efficient level.

Placing strict liability on manufacturers and distributors would not remove intervening tortfeasors' disincentives to engage in harmful conduct. If the handgun user or owner can be identified and is not judgment proof, he should be liable to the manufacturer or distributor for indemnification. Moreover, a person who injures another person with a handgun will often face criminal prosecution and the social stigma associated with his crime.

The manufacture and distribution of handguns is not the only risky activity that creates external costs. What distinguishes this activity, however, is that the victims' activities cannot be controlled in a meaningful way by allowing the loss to remain on them; nor can the activities of other injurers, since they are likely to be unknown or judgment proof. Consequently, the most effective method of controlling excessive harmful activity and thereby reducing social costs is to place the burden on handgun manufacturers and distributors.

Other considerations of public policy support strict liability in this context. A common sentiment is that it is more equitable that those producing guns pay for the injuries they cause than that innocent victims pay. ${ }^{29}$ In addition, manufacturers and distributors are better able to spread the risk of handgun injury than are the victims: thus the familiar strict liability rationale of risk allocation $^{30}$ supports such a regime here, too.

\section{The Abnormally Dangerous Activities Doctrine}

Strict liability for the manufacture and distribution of handguns rests on a solid legal foundation: the common law tort doctrine that applies strict liability to activities deemed ultrahazardous or abnormally dangerous. As noted above, this doctrine is economically defensible because in ultrahazardous ac-

28 See notes 152-53 and accompanying text below (on handgun identification). In addition to this new insurance (which would become an ordinary operating expense), the company has its entire equity as a resource to pay for its costly conduct. It may be necessary to regulate undercapitalized companies through mandatory liability insurance or minimum capital levels, since otherwise these companies will have incentives to engage in overly risky activity. See note 155 and accompanying text below.

29 First-party insurance helps to compensate victims but does nothing to reduce the activity levels of injurers. Only insofar as purchasers bear the cost of insurance will a drop in injurer activity levels result.

so See, e.g., Escola, 150 P.2d at 440-41 (Traynor, J., concurring). 
tivities, controlling injurer, rather than victim, activity levels is more effective in reducing total costs. For the same reason, manufacturer's strict liability is a superior rule for handgun injuries. The similar economic justifications suggest that the manufacture and distribution of handguns may properly be classified as an ultrahazardous activity. And, indeed, handgun manufacture and distribution falls squarely within the criteria for applying the common law doctrine.

This section first traces the evolution of the ultrahazardous activities doctrine into the current doctrine of abnormally dangerous activities, embodied in the Restatement (Second) of Torts. ${ }^{31}$ It then examines the doctrine's applicability to the manufacture and distribution of consumer products in general, setting the stage for the next section, which applies the doctrine to handgun manufacturers and distributors.

\section{A. Historical Development}

The doctrine of ultrahazardous activities originated in the famous case of Rylands $v$. Fletcher. ${ }^{32}$ The rule of the case, as it emerged from subsequent English decisions, is that the defendant will be liable when he damages another by a thing or activity unduly dangerous and inappropriate to the place where it is maintained, in light of the character of that place and its surroundings. ${ }^{33}$ Early confusion about what the case actually stood for led to varying degrees of acceptance by the American courts. ${ }^{34}$ But

31 Restatement (Second) of Torts (1977) ("Second Restatement").

${ }^{32}$ Fletcher v. Rylands, 3 H. \& C. 774, 159 Eng. Rep. 737 (1865), rev'd L.R. 1 Ex. 265 (1866), aff'd as Rylands v. Fletcher, L.R. 3 H.L. 330 (1868).

ss See W. Page Keeton, Dan B. Dobbs, Robert E. Keeton, and David G. Owen, Prosser and Keeton on the Law of Torts 547-48 (5th ed. 1984) ("Prosser and Keeton on Torts"). See also Abraham Harari, The Place of Negligence in the Law of Torts 147-51 (1962); William Lloyd Prosser, Selected Topics on the Law of Torts 147 (1953) ("Selected Topics").

s4 The confusion arose because of Baron Blackburn's comments in the Exchequer Chamber, which premised liability on the broader principle that strict liability applies to all those who bring and keep on their land any thing likely to do mischief if that thing escapes. See Prosser, Selected Topics at 137 (cited in note 33).

Lord Cairns had limited the basis of liability to "nonnatural" uses, but American courts often overlooked this qualification, which possibly explains the inconsistent treatment. Within eight years of the final English decision, five American courts had registered their own evaluations of the rule: Ball v. Nye, 99 Mass. 582 (1868) (adopting the rule); Cahill v. Eastman, 18 Minn. 324 (1872) (adopting the rule); Brown v. Collins, 53 N.H. 442 (1873) (rejecting the rule); Losee v. Buchanan, 51 N.Y. 476 (1873) (rejecting the rule); and Marshall v. Welwood, 38 N.J.L. 339 (1876) (rejecting the rule). "Rylands v. Fletcher was treated as holding that the defendant is absolutely liable in all cases whenever anything under his control escapes and does damage. In other words, the law of the case was misstated, and as misstated rejected, on facts to which it had no proper application in the first place." Prosser 
once it was adopted in America, the doctrine developed beyond the English rule.

A significant manifestation of the unique flavor of the American rule came with the first Restatement of Torts, which attempted to codify the principles of the Rylands-type cases under the heading of "ultrahazardous activities." According to the Restatement, an activity is ultrahazardous when it "necessarily involves a risk of serious harm to the person, land or chattels of others which cannot be eliminated by the exercise of the utmost care,"ss and where the activity "is not a matter of common usage." "se This formulation differed from the pure English rule in not directly considering the relation of the activity to its surroundings, in requiring extreme dangerousness in the activity, and in exempting activities where due care would eliminate the danger. ${ }^{37}$

It is not clear that the American cases dealing with the ultrahazardous activity doctrine supported the Restatement formulation. ${ }^{38}$ The early cases had involved related doctrines that played roles in the rule's genesis-trespass, strict liability for dangerous animals, and nuisance ${ }^{39}$-and often it was not possible to discern the boundaries between those bases for liability and the Rylands doctrine itself. The Restatement formulation attempted to develop a rule that stated the principle of Rylands in light of those related bodies of strict liability. Thus it is not surprising to find a dearth of case law support for its specific formulation of the rule. In any case, whether the Restatement got it right is now less important than its impact on subsequent cases.

The underlying rationale for the rule initially was one of public policy: where an actor introduces into the community an unusual risk, she (rather than a wholly innocent victim) should pay for the cost of accidents attributable to the risk, regardless of due care. ${ }^{40}$ However, some courts were uncomfortable with the idea of

and Keeton on Torts at 548 (cited in note 33).

${ }^{3 s}$ Restatement of Torts $\S 520$ (a) (1938).

ss Id. at $\$ 520$ (b).

s7 Prosser and Keeton on Torts at 551 (cited in note 33). See also Prosser, Selected Topics at 158 (cited in note 33).

ss Prosser and Keeton on Torts at 551 (cited in note 33).

30 For general background, see Prosser, Selected Topics at 137-49 (cited in note 33).

so See Bradford Glycerine Co. v. St. Marys Woolen Mfg. Co., 60 Ohio St. 560, 574-75, 54 N.E. 528, 531 (1899); Kall v. Carruthers, 59 Cal.App. 555, 211 P. 43 (1922); Green v. General Petroleum Corp., 205 Cal. 328, 333-34, 270 P. 952, 955 (1928). See also Spano v. Perini Corp., 25 N.Y.2d 11, 17-18, 250 N.E.2d 31, 35 (1969) (discussing earlier cases and the rationale for liability); Chavez v. Southern Pacific Transp. Co., 413 F.Supp. 1203, 1207-08 (E.D. Cal. 1976). 
strict liability, fearing it would overly burden defendants and inhibit commerce and industrialization. ${ }^{41}$

Despite the problems courts have had in applying the rule-an unclear understanding of its parameters, a suspicion of strict liability in general, and the concern for protecting commercial development-a wide variety of activities have been held to fall within the rule. Blasting cases are ubiquitous; ${ }^{42}$ the storage and transportation of gasoline ${ }^{43}$ and the storage and transportation of explosives ${ }^{44}$ are also activities that frequently fall within the rule. Other activities considered ultrahazardous include fumigating with hydrogen cyanide, ${ }^{46}$ cropdusting, ${ }^{46}$ releasing fluorine gas in manufacturing, ${ }^{47}$ creating sonic booms, ${ }^{48}$ pile driving ${ }^{49}$ transporting liquefied propane gas, ${ }^{50}$ and rocket launching. ${ }^{51}$ There are, not surprisingly, also cases whose facts resemble those in Rylands. ${ }^{52}$

The next significant step in the development of the ultrahazardous activities doctrine was the reformulation adopted in 1977 by the Second Restatement. The Second Restatement refined the previous view by listing six factors to be considered in determining whether an activity is "abnormally dangerous," the new la-

41 See City Water Power Co. v. City of Fergus Falls, 113 Minn. 33, 35-36, 128 N.W. 817, 818 (1910); Rose v. Socony-Vacuum Corp., 54 R.I. 411, 173 A. 627 (1934); Fritz v. DuPont Co., 45 Del. 427, 437-38, 75 A.2d 256, 261 (1950). See also Harper v. Regency Dev. Co., Inc., 399 So.2d 248 (Ala. 1981) (majority rationalizes the doctrine in terms of negligence, dissent focuses on dire implications of the rule for commerce).

42 See, e.g., Correa v. Curbey, 124 Ariz. 480, 605 P.2d 458 (App. 1979); M.W. Worley Constr. Co. v. Hungerford, Inc., 215 Va. 377, 210 S.E.2d 161 (1974); Davis v. L \& W Constr. Co., 176 N.W.2d 223 (Iowa 1970); Catholic Welfare Guild, Inc. v. Brodney Corp., 58 Del. 246, 208 A.2d 301 (Super. Ct. 1964).

43 As to storage of gasoline, see City of Northglenn, Colo. v. Chevron USA, Inc., 519 F.Supp. 515 (D. Colo. 1981); Yommer v. McKenzie, 255 Md. 220, 257 A.2d 138 (1969). As to transportation of gasoline, see, e.g., Siegler v. Kuhlman, 81 Wash.2d 448, 502 P.2d 1181 (1972) (implicitly refusing to apply the common carrier exception as articulated by the Second Restatement § 521). But contrast Ozark Indus., Inc. v. Stubbs Transports, Inc., 351 F.Supp. 351 (W.D. Ark. 1972); Collins v. Liquid Transporters, 262 S.W.2d 382 (Ky. 1953).

"As to storage of explosives, see Koster \& Wythe v. Massey, 293 F.2d 922 (9th Cir. 1961) (incendiary bomb); Yukon Equip., Inc. v. Fireman's Fund Ins. Co., 585 P.2d 1206 (Alaska 1978). But contrast Bridges v. Kentucky Stone Co., Inc., 425 N.E.2d 125 (Ind. 1981). As to transportation of explosives, see, e.g., Chavez, 413 F.Supp. at 1203.

${ }^{45}$ Luthringer v. Moore, 31 Cal.2d 489, 190 P.2d 1 (1948).

${ }^{48}$ Loe v. Lenhardt, 227 Or. 242, 362 P.2d 312 (1961).

47 Dutton v. Rocky Mountain Phosphates, 438 P.2d 674 (Mont. 1968). But contrast Fritz, 75 A.2d at 256.

4 Nelms v. Laird, 442 F.2d 1163 (4th Cir. 1971).

49 Lowry Hill Properties, Inc. v. Ashbach Constr. Co., 291 Minn. 429, 194 N.W.2d 767 (1971).

${ }^{30}$ National Steel Serv. Center v. Gibbons, 319 N.W.2d 269 (Iowa 1982).

${ }^{11}$ Smith v. Lockheed Propulsion Co., 247 Cal.App.2d 774, 56 Cal.Rptr. 128 (1967).

${ }^{32}$ Clark-Aiken Co. v. Cromwell-Wright Co., Inc., 367 Mass. 70, 323 N.E.2d 876 (1975). 
bel for what the First Restatement called "ultrahazardous":

(a) existence of a high degree of risk of some harm to the person, land or chattels of others;

(b) likelihood that the harm that results from it will be great;

(c) inability to eliminate the risk by the exercise of reasonable care;

(d) extent to which the activity is not a matter of common usage;

(e) inappropriateness of the activity to the place where it is carried on; and

(f) extent to which its value to the community is outweighed by its dangerous attributes. ${ }^{53}$

These factors restore the consideration of location, which was missing from the previous formulation, and flesh out issues considered by the courts as inherent in the old formulation. ${ }^{54}$ The impact of these changes is unclear. One commentator suggests that this test is now akin to the negligence standard, ${ }^{\mathrm{sB}}$ another commentator heralds the return to a flexible standard, ${ }^{56}$ and one court has called the formulation influential in "extending the ambit of strict liability." 37

B. The Abnormally Dangerous Activities Doctrine and the Manufacture of Consumer Products

Classifying the manufacture and distribution of handguns as an abnormally dangerous activity would be an extension of past doctrine. It would make the production of a consumer product the basis for liability, while most cases decided under the doctrine have predicated liability on use of a product. For example, it is the contractor and not the manufacturer who is liable for accidents in the use of explosives, and it is the carrier and not the producer

ss Second Restatement $\$ 520$.

st Since nearly all ultrahazardous activities relate somehow to land use, the locational element-though not explicitly mentioned in older formulations of the rule-was ever-present in the cases. The Second Restatement reflects this in factor (e). Factor (f), the value to the community, reflects the common law courts' interest in the adverse effects of a rule of strict liability on industry. Factors (a) and (b) together specify the meaning of "risk of serious harm" under the old formulation.

ss See Prosser and Keeton on Torts at 555 (cited in note 33).

so See Comment, Strict Liability for Hazardous Enterprises: Returning to a Flexible Analysis, 9 UCLA-Alaska L. Rev. 67, 75-82 (1979).

${ }^{67}$ City of Northglenn, 519 F.Supp. at 516. 
who is liable for a gasoline spill.

Certainly manufacture and distribution separately are "activities"-just as much as any other steps in the process of injecting a product into the stream of commerce and human activity. Thus, when critics object to characterizing these as ultrahazardous activities, ${ }^{58}$ they must argue that production and distribution are not ultrahazardous. And indeed, one might reason that while the use of a product might be ultrahazardous, its manufacture is not inherently dangerous and so should fall outside the doctrine.

Nevertheless, there is authority for characterizing the manufacture and distribution of a dangerous consumer product as an ultrahazardous activity. In Chapman Chemical Company v. Taylor, ${ }^{30}$ the defendant chemical company produced a pesticide, known as 2-4-D, that unexpectedly had the propensity to float great distances. The chemical was harmful to cotton and damaged the plaintiff"s crop. Although the trial court characterized as "negligent" the defendant's failure to fully test this "inherently dangerous" product, the Supreme Court of Arkansas affirmed on a theory of strict liability, citing the First Restatement and several cases based on the doctrine of ultrahazardous activities:

$[\mathrm{H}]$ ere we are dealing with an extra hazardous chemical known to be highly dangerous. . . .

If one casts into the air a substance which he knows may do damage to others ... principles of elementary justice [and] the best public policy require that ... if he releases such a substance . . . in indifference to the damage that may be done, the rule of strict liability should be applied. ${ }^{61}$

In essence, the court held the manufacturer responsible for "casting into the air" this harmful pesticide because it had sold the dangerous product. ${ }^{62}$ 1984).

${ }^{88}$ See, e.g., Martin v. Harrington \& Richardson, Inc., 743 F.2d 1200, 1204 (7th Cir.

B8 215 Ark. 630, 222 S.W.2d 820 (1949).

Bo 222 S.W.2d at 826.

${ }^{81}$ Id. at 826-27.

${ }^{32}$ Language in the opinion points to the company's failure to test for the floating characteristics of the pesticide as a factor in the issue of liability. Although this suggests a breach of duty, it is actually a red herring. The court makes clear that the company would be "charged with the knowledge which tests would have revealed." Id. at 827 . Had the company actually made the tests, discovered this characteristic, and still sold the product, according to the court's reasoning liability would necessarily have followed. Perhaps the company may have avoided liability by introducing the pesticide with an adequate warning; the important point here is that the court was willing to hold a manufacturer liable on a theory of ultrahazardous activities. 
Other cases involving dangerous products also entertain the possibility of manufacturers' strict liability under the abnormally dangerous activities doctrine. In response to a claim that the manufacture of an investigational drug was an abnormally dangerous activity, the Arizona Court of Appeals noted that "traditionally" the doctrine contemplated some notion of "geographic proximity" and declined an "innovative application" of the doctrine because production of the particular drug did not involve sufficiently great or unusual risks ${ }^{63}$ and because the plaintiff had voluntarily assumed the risk. ${ }^{64}$ In a similar challenge to the marketing of chemically treated grain, a New Mexico court analyzed whether the activity satisfied the Restatement factors. The court ruled that the grain treatment involved was of common usage and that due care would have eliminated the danger. ${ }^{65}$

A case of special interest is Indiana Harbor Belt Railroad Co. v. American Cyanamid $\mathrm{Co}^{68}$ There the plaintiffs sued American Cyanamid as "manufacturer and shipper" of acrylonitrile, a hazardous and toxic substance, when the substance leaked from a railway freight car in transit. The court refused to dismiss the cause of action based on ultrahazardous activities, stating that the defendant "acted 'for his own purposes and profit' in introducing the peril into the community." ${ }^{37}$ The court looked to an earlier state case to frame its ultimate inquiry: "Are there products with such dangerous qualities that they should not be placed in the stream of commerce; or if so placed that the risk of harm to the public is so great that liability should be imposed on the manufacturer if harm befalls one exposed to the product?"68 The court clearly indicated liability of the manufacturer was not based on transporting the acrylonitrile but rather on arranging for its transportation. ${ }^{69}$ The court's focus on the role of the manufacturer in injecting the dangerous though nondefective product into the stream of commerce is a significant recognition of the appropriateness of applying the abnormally dangerous activities doctrine to manufacturers of dan-

6s Gaston v. Hunter, 121 Ariz. 33, 48-49, 588 P.2d 326, $341-42$ (1978).

of Gaston, 588 P.2d at 341.

6s First Nat. Bank, Albuquerque v. Nor-Am Agri. Prods., Inc., 88 N.M. 74, 79, 537 P.2d 682, 687 (App. 1975). The New Mexico court used the older "ultrahazardous activities" formulation.

o6 517 F.Supp. 314 (N.D. Ill. 1981).

62 Id. at 317.

os Id. at 318, quoting Ruggeri v. Minnesota Mining \& Mfg. Co., 63 Ill.App.3d 525, 528, 380 N.E.2d 445, 447 (1978) (products liability case).

69 517 F.Supp. at $318-19$ n.3. "The plaintiffs here have only sought to impose liability upon the manufacturer, who arranged for the acrylonitrile to be transported." Id. 
gerous products generally.

As the discussion of these cases indicates, manufacturers' liability for abnormally dangerous activities may overlap with strict products liability. This is not surprising, however, given the role that the ultrahazardous activities doctrine played in the development of strict products liability. ${ }^{70}$ If no theory of products liability had ever evolved, many of the same results might have been reached by characterizing the distribution of defective products as an abnormally dangerous activity. ${ }^{71}$ But the availability of strict products liability has, as a practical matter, preempted this approach for consumer products.

A comment about "common usage" from the Second Restatement further supports application of the doctrine to a manufacturer of a consumer product: "Likewise the manufacture, storage, transportation and use of high explosives ... are not matters of common usage." ${ }^{.2}$ The storage, transportation, and use of explosives comport with the traditional interpretation of abnormally dangerous activities; ${ }^{73}$ in including "manufacture" among the activities listed, the Restatement appears to recognize the equal or dominant role this activity plays in the overall creation of risk.

In practical terms, manufacturers may have eluded liability for "traditional" ultrahazardous activities simply because plaintiffs had no need to reach the manufacturers. The intermediate actors-for example, carriers or contractors using dangerous materials-were usually well-heeled entities in and of themselves; plaintiffs thus had little incentive to extend the ultrahazardous doctrine to a party one step removed. But where the immediate actor is unknown or insolvent, as is often the case with handgun injuries, ${ }^{74}$

${ }^{\text {тo }}$ See, e.g., Cavan v. General Motors Corp., 280 Or. 455, 571 P.2d 1249 (1977) (recognizing the ultrahazardous activities doctrine as a step in the evolution of strict products liability in Oregon, but stating that the doctrine no longer has applicability in a products case, having been displaced by Second Restatement $\$ 402 A)$; Handy v. Uniroyal, Inc., 327 F.Supp. 596 (D. Del. 1971) (tracing the development of the ultrahazardous activities doctrine and its interplay with developing products liability law).

71 Apparently the courts have not greeted this characterization with favor. See Handy, 327 F.Supp. at 605 (citing a host of cases that reject the contention, at least as proposed in those cases). But see Johnson v. Star Mach. Co., 270 Or. 694, 726-28, 530 P.2d 53, 67-68 (1974) (Tongue, J., dissenting) (stressing the similarity between an action for injuries caused by a dangerously defective product and an action for injuries from an ultrahazardous product or condition). There is, however, a significant difference between the activity of distributing products that occasionally cause injury when defective and distributing products that are always dangerous and that frequently cause injury.

${ }^{72}$ Second Restatement $\$ 520$, comment i.

73 Id.

74 See text at notes $27-28$ above. 
plaintiffs must search beyond that actor for another responsible party.

\section{Application of the Abnormally Dangerous ACtivities Doctrine to the MANUfaCture AND Distribution of HaNDGUNS}

This section shows how the abnormally dangerous activities doctrine of the Second Restatement can be fruitfully applied to the manufacture and distribution of handguns. The section first surveys the case law and commentary on this specific topic. Next, the section argues that handgun manufacture and distribution generally qualifies as a proximate cause of handgun-related injuries, since such injuries are foreseeable at the time of production. The section then examines the factors defining abnormally dangerous activities and finds that handgun production fits comfortably within them. It next shows how the reach of the strict liability principle can be confined to handgun production and distribution rather than be left to encompass a wide range of "dangerous" activities. The section concludes by discussing the doctrine in practice.

\section{A. Cases and Commentary}

The only case so far to recognize a cause of action against a handgun manufacturer or distributor under the abnormally dangerous activities doctrine is Richman v. Charter Arms Corp. ${ }^{75}$ There, the district court interpreted Louisiana law to permit a wrongful death action under the ultrahazardous activities doctrine for the rape and murder of the plaintiff's daughter. ${ }^{76}$ The Fifth Circuit, however, reversed the decision, holding that the action was prohibited under the peculiar ultrahazardous activities doctrine developed from the Louisiana civil code. ${ }^{77}$

A few other courts have conscientiously analyzed causes of action against handgun manufacturers based on the abnormally dan-

75571 F.Supp. 192 (E.D. La. 1983), rev'd as Perkins v. F.I.E. Corp., 762 F.2d 1250 (5th Cir. 1985).

76 571 F.Supp. at 208-09.

77762 F.2d at 1254-69, discussing the ultrahazardous activities doctrine developed from La. Civ. Code Annot. arts. 667-69 (West 1980). The lower court had held that the cause of action was permitted under the Second Restatement. 571 F.Supp. at 208-09. The court of appeals added in dicta that it believed the plaintiff would fail under the Restatement as well. 762 F.2d at 1265 n.43. 
gerous doctrine, ${ }^{78}$ but none of these have allowed the action to stand. The courts have pointed to several perceived shortcomings in the application of the ultrahazardous activities doctrine to handgun manufacturers. Most frequently, courts distinguish the use of a handgun from its marketing, ${ }^{79}$ arguing that while the use of a handgun might be an ultrahazardous activity, the marketing of such an item is not particularly dangerous. ${ }^{80}$ Courts also have objected to the characterization of a sale of a product as an activity, ${ }^{81}$ the move away from the doctrine's traditional relation to land use, ${ }^{82}$ and the application of the "common usage" criterion to the handgun's marketing. ${ }^{83}$

These objections are hollow in light of a full understanding of the doctrine of abnormally dangerous activities. The distinction between marketing and use is one without a difference, ${ }^{84}$ the relation to land use is but a proxy for the totality of the circumstances, ${ }^{85}$ and the manufacture of handguns is not of common usage even if owning a handgun might be. ${ }^{86}$

Two other criticisms of the application of the abnormally dangerous activities doctrine to the manufacture and distribution of handguns are: 1) that application to handguns logically will lead to the application of the doctrine to manufacturers of other products, such as of kitchen knives, automobiles, tobacco products, and liquor; $^{87}$ and 2) that extending liability rules in a situation as pub-

${ }^{78}$ See Martin v. Harrington and Richardson, Inc., 743 F.2d 1200 (7th Cir. 1984); Riordan v. Int'l. Armament Corp., 132 Ill.App.3d 642, 477 N.E.2d 1293 (1985); Kelley v. R. G. Industries, Inc., 304 Md. 124, 497 A.2d 1143 (1985); Burkett v. Freedom Arms, Inc., 299 Or. 55, 704 P.2d 118 (1985).

79 See Perkins, 762 F.2d at 1265 n.43; Martin, 743 F.2d at 1203-06; Burkett, 704 P.2d at 121-22; Riordan, 477 N.E.2d at 1297.

so See, e.g, Martin, 743 F.2d at 1204.

81 Id. This decision ignored an earlier opinion within its own circuit (which had applied the same state's law), Indiana Harbor Belt R.R., 517 F.Supp. 314, discussed above at text accompanying notes 66-69. The Martin court stated that "we have found no decision other than Richman that has held that the lawful sale of a non-defective product can be an ultrahazardous activity." 743 F.2d at 1204. But the gist of the Indiana Harbor decision was that the shipping (as opposed to the transportation) of a dangerous chemical, an incident of its sale, could be an ultrahazardous activity - for which liability would rest not on the transporter, but on the party that injected the nondefective but dangerous product into the stream of commerce.

82 Kelley, 497 A.2d at 1147.

ss Perkins, 762 F.2d at 1265 n.43.

84 See part II-B above (notes 58-74 and accompanying text) (arguing that the manufacture and distribution of a consumer product can be classified as an abnormally dangerous activity).

${ }^{\text {so }}$ See notes 129-32 and accompanying text below.

${ }^{86}$ See notes 118-28 and accompanying text below.

${ }^{87}$ See, e.g., Martin, 743 F.2d at 1204; Perkins, 762 F.2d at 1269. 
licly controversial as handguns ought to be left to the legislatures and not to the courts. ${ }^{88}$ The former criticism will be explored in a later section of this comment. ${ }^{88}$ In response to the latter, one can argue that it is precisely because this issue is so controversial that legislatures have not taken action, choosing instead to leave the responsibility to the courts. ${ }^{80}$

The commentaries on this issue reiterate the objections raised by the courts and add several others. ${ }^{91}$ Their approaches range from a thorough analysis of the six factors of the Second Restatement $^{92}$ to a short treatment based on a few particular aspects of the doctrine. ${ }^{93}$ A major contribution of the commentaries is to refute the claim that the manufacture and distribution of handguns has no utility, ${ }^{94}$ a claim stemming conceptually from the products liability cause of action..$^{95}$ In a perfect world, an activity with a net social cost would continue only if its private benefit exceeded zero. Assuming the social costs of an activity are measurable, over time a rational society would tax and regulate the activity, reducing the

s. See, e.g., Note, Handguns and Products Liability, 97 Harv. L. Rev. 1912, 1924-27 (1984). See also Patterson v. Gesellschaft, 608 F.Supp. 1206, 1216 (N.D. Tex. 1985).

see part III-D-2 below (notes 140-43 and accompanying text).

90 It should be pointed out that some potential legislative program might be even more efficient than the judicial course advocated in this comment. A legislative solution could be more detailed and more carefully tailored to the facts of handgun markets. Moreover, it might be structured to avoid the inevitable costs associated with litigation. Nevertheless, the strict liability rule is better than the negligence rule that exists today and is within the general common law power of the courts to apply.

92 See Donald E. Santarelli and Nicholas E. Calio, Turning the Gun on Tort Law: Aiming at Courts to Take Products Liability to the Limit, 14 St. Mary's L. J. 471, 498-501 (1983); Note, 97 Harv. L. Rev. 1912 (cited in note 88); Note, Legal Limits of a Handgun Manufacturer's Liability for the Criminal Acts of Third Persons, 49 Mo. L. Rev. 830 (1984); Note, Richman v. Charter Arms, 11 J. Contemp. L. 601 (1985).

${ }^{92}$ See Note, $11 \mathrm{~J}$. Contemp. L. at 609-16 (cited in note 91).

93 See Note, 97 Harv. L. Rev. at 1923-24 (cited in note 88).

" See, e.g., Note, 49 Mo. L. Rev. at 843 (cited in note 91). See also Richman, 571 F.Supp. at 202. Some commentaries point to the jobs created by handgun manufacturers as part of the utility created by the activity. See, e.g., Santarelli and Calio, 14 St. Mary's L. J. at 499 (cited in note 91 ). While the effect of the activity on the direct community is factor (f) in the Second Restatement's analysis, the utility associated with capital is not unique to a particular activity over the long run. Jobs and tax dollars lost to one community as a result of disinvestment eventually will surface elsewhere, and hence from a society's point of view it is not meaningful to associate such a generic utility with a particular activity.

${ }^{25}$ The lack of utility of a product, or more precisely a net disutility of that product, would render it (or its particular design) unreasonably dangerous under a risk/utility analysis and would result in a manufacturer's strict liability. The manufacturer is actually held liable, then, for distributing a product with a net disutility to society, a result arguably reached under traditional negligence principles. This position on the utility of the product leads to a like position on the utility of the activity of distributing that product, a position in this case inconsistent with the doctrine of ultrahazardous activities. 
private benefit and increasing the net social benefit so that, at a minimum, there was no net social cost.

Thus, activities with net social costs will not endure. To be sure, our world is less than perfect, but since the manufacture and distribution of handguns is a mature industry, and since our government tax and regulatory mechanisms are well-developed, it would be reasonable to conclude that the manufacture and distribution of handguns produces a net social benefit. This conclusion does not mean, however, that the activity should continue at any activity level.

\section{B. Foreseeability of Harm}

Handgun manufacturers and distributors clearly are "but for" causes of handgun-related injuries since they directly and indirectly put the weapons into the hands of those who pull the triggers. ${ }^{98}$ To hold manufacturers and distributors liable under the $a b$ normally dangerous activities doctrine, however, the law requires that their actions be "proximate" causes of handgun injuries. The question of proximate cause in this context is complicated by the fact that the immediate infliction of handgun injuries is by intervening parties, and often by criminal behavior. But the chief issue in determining proximate cause is whether the ultimate injury is foreseeable to the defendant, and handgun manufacturers and distributors certainly can foresee the eventual injuries.

In the first place, the requirement of foreseeability in abnormally dangerous activities cases is modest at best. The Second Restatement stipulates that the rule applies only to those harms "within the scope of the abnormal risk." But it also states that contributing acts of third persons, animals, and nature do not absolve the enterpriser from responsibility. ${ }^{98}$ As to intentional intervention, the Second Restatement expresses no opinion. ${ }^{89}$ At least one court has held that in cases involving ultrahazardous activity, foreseeability is not even required. ${ }^{100}$

Second, whatever the status of the foreseeability requirement,

* See Windle Turley, Manufacturers' and Suppliers' Liability to Handgun Victims, 10 N. Ky. L. Rev. 41, 47-49 (1982). See also Wright, Rossi, Daly, and Weber-Burdin, eds., U.S. Department of Justice, Weapons, Crime, and Violence in America (1981).

${ }^{87}$ Second Restatement $\S 519$, comment e.

${ }^{88}$ Id. § 522.

'9 Id. (caveat). See also Yukon Equip. v. Fireman's Fund Ins. Co., 585 P.2d 1206 (Alaska 1978) (holding the criminal acts of thieves in detonating stored explosives foreseeable for purposes of the rule).

100 Davis v. L \& W Constr. Co., 176 N.W.2d 223 (Iowa 1970). 
the weight of authority recognizes that criminal use of handguns is foreseeable. ${ }^{101}$ Intervening misconduct, either intentional or criminal, is not always a bar to civil liability. ${ }^{102}$ "There are . . . situations in which the defendant will be held liable because his affirmative conduct has greatly increased the risk of harm to the plaintiff through the criminal acts of others." handguns stems from the use or threatened use of lethal force: producers intend handguns to injure. Handgun injuries-including those caused by criminal acts-are the expected, foreseeable, and recurrent result of marketing handguns. ${ }^{104}$ Accordingly, criminal intervention does not sever the causal chain.

The most forceful judicial statement of this view is the recent decision by the Court of Appeals of Maryland in Kelley v. R.G. Industries, Inc. ${ }^{105}$ There the court emphasized the foreseeability of criminal use of the inexpensive small handguns known as "Saturday Night Specials"::106 "the manufacturer or marketer of a Satur-

${ }^{101}$ See Steven P. Teret and Garen J. Wintemute, Handgun Injuries: The Epidemiologic Evidence for Assessing Legal Responsibility, 6 Hamline L. Rev. 341, 342-45 (1983). But contrast David T. Hardy, Legal Restrictions of Firearm Ownership as an Answer to Violent Crime: What was the Question?, 6 Hamline L. Rev. 391, 394-96 (1983) (arguing that there is no relationship between firearm ownership and violent crime levels). However, once sufficient time has passed to render the current stock of handguns nonoperational, at least one point on the activity level/injury level curve will be known: at an activity level of zero (i.e. when there are no handguns in society), there can be no handgun injuries.

${ }_{102}$ See Prosser and Keeton on Torts at 201-03 (cited in note 33).

${ }^{105}$ Id. at 203. See, e.g., Warner v. Arnold, 133 Ga.App. 174, 210 S.E.2d 350 (1974) (landlord not relieved of liability for burglary and arson where tenant had complained of inadequate lock); Hines v. Garrett, 131 Va. 125, 108 S.E. 690 (1921) (rape of passenger negligently discharged by railroad in unsafe neighborhood held foreseeable).

${ }^{104}$ See, e.g., Decker v. Gibson Prods. Co. of Albany, Inc., 679 F.2d 212, 215-16 (11th Cir. 1982) (holding that foreseeability of ex-convict murdering his former wife with a handgun was a jury question). See also McLaughlin v. United States, 106 S.Ct. 1677 (1986), in which the Supreme Court discussed the inherent dangerousness of handguns even when unloaded:

First, a gun is an article that is typically and characteristically dangerous; the use for which it is manufactured and sold is a dangerous one, and the law reasonably may presume that such an article is always dangerous. . . . In addition, the display of a gun instills fear in the average citizen; as a consequence, it creates an immediate danger that a violent response will ensue.

Id. at 1678 (footnotes omitted).

105304 Md. 124, 497 A.2d 1143 (1985).

${ }^{108}$ The court restricted its reasoning, and its creation of a new strict liability niche, to Saturday Night Specials. However, the court need not and should not have limited its treatment of forseeability in this way. Strict liability only for Saturday Night Specials will probably cause their prices to rise well above those of other, better-made handguns. While some users will no longer buy handguns at all, others will simply switch to the other guns. Only strict liability for all handguns will achieve the full potential reduction in activity levels and hence social cost. 
day Night Special knows or ought to know that the chief use of the product is for criminal activity. Such criminal use ... . [is] clearly foreseeable by the manufacturers and sellers of Saturday Night Specials."107

From an economic point of view, this expansive notion of causation is completely sound. Once an inference of causation is justified, ${ }^{108}$ calculations of efficiency need be based only upon statistical correlations between activity and losses. To establish causation, the economist examines the relationship between handgun manufacture and injury costs at various levels of production and victim activity and asks only whether the losses saved by a reduction in manufacturing activity overcome countervailing losses incurred by inaccurate risk spreading and by changes in victim behavior. ${ }^{109}$ This perception of causation avoids the problem of spurious correlation by asking not so much whether a particular action produced a particular result, but rather whether in the future, modification or reduction of the activity could avoid a particular outcome in a cost-effective manner. Some correlation will exist between a wide variety of activities that determine the injury levels and a particular class of injuries, thus constituting causal relationships. But only a few, if any, will be correlated strongly enough to make a change in activity welfare-increasing-and only these activities would be classified as proximate causes. ${ }^{110}$ Hence, this definition of proxi-

107497 A.2d at 1159.

${ }^{108}$ In many cases, causation cannot be inferred from correlation; for example, stock returns of two particular issues might be highly correlated but caused by a third factor, such as underlying economic trends. Because the relationship between supplying handguns to the market and handgun injuries is sequential and physically dependent, an inference of causation from statistical correlation is justified.

${ }^{209}$ See note 23 and accompanying text above.

110 For example, one could attempt to control handgun injuries by making the manufacturer of the steel that constitutes the handgun strictly liable to the victim. Assuming he cannot discriminate in pricing between steel used for handguns and that used for less risky purposes, the steel manufacturer will increase the price of steel generally to reflect his costs of liability, and some reduction in quantity demanded will result. While very little change in handgun injuries will occur as steel demand adjusts to the new price, much useful steel consumption is lost and the result is probably a net social loss. Hence, the manufacture of steel would not be a proximate cause of handgun injuries.

In reality, many activities will be nontrivially correlated to accident costs. The best solution in this situation is to charge each of the activities its proportionate share of total injury cost. If allocation is too administratively burdensome, the second-best solution is to charge the entire amount of injury costs to the activity that has the greatest impact on total injury cost. This will improve social welfare as long as the correlation is sufficient to be a proximate cause as previously defined.

For example, in the case of handgun injuries, the prime causal factor could be either the manufacture of handguns or the manufacture of ammunition. It is an implicit assumption of this comment that the handgun element outweighs all others that remain in the total cost 
mate cause does not produce infinite causation.111 Since changing the activities of manufacturers will change the level of handgun injuries the most, the manufacture and distribution of handguns can be said to be a proximate cause of handgun injuries under this definition of causation.

\section{The Restatement Factors Applied}

The six factors of the Second Restatement's formulation of the abnormally dangerous activities doctrine describe situations in which a risky activity should pay its way regardless of negligence. Besides the political desire to place liability on the initial creator of the harm when two nonnegligent parties are involved, strong economic reasons further support the rule of strict liability. ${ }^{112}$ The factors listed in the Second Restatement reflect the underlying economic policy of controlling the party whose unchecked activity levels would be most costly.113 Each factor is an indicator of cases in which reducing injurer activity levels through imposing liability is likely to be more effective in maximizing net social benefits than is reducing victim activity levels through a rule of negligence.

1. Probability of harm. The first of the six Restatement factors is the existence of a high risk of harm to the person. ${ }^{114} \mathrm{Al}-$ though the data regarding the dangerousness of handguns are notoriously imprecise and are open to various interpretations, some estimates are useful. Approximately 22,000 Americans die annually from handgun injuries, and the estimated total cost of injuries and deaths is approximately $\$ 20$ billion. ${ }^{115}$ Numbers are not necessary to justify the commonsense conclusion that handguns are particularly dangerous items-because of their lethal power and because

function once the impact of criminals and victims have been removed. If another element, say ammunition, outweighed handguns in the total cost function, then the analysis would dictate that this activity be charged the entire amount. The possibility exists, however, that it might not be burdensome to allocate the total cost among the remaining significant activities under a scheme of comparative strict liability.

111 In fact, in some situations, no activity may be strongly enough correlated to injuries to make a general reduction in that activity through liability efficient. In such cases, one solution would be to fund accident costs by taxing the related activities in proportion to their correlation.

${ }_{112}$ See Part I-B above (notes 24-29 and accompanying text).

${ }^{113}$ See William M. Landes and Richard A. Posner, The Positive Economic Theory Of Tort Law, 15 Ga. L. Rev. 851, 907-08 (1981).

114 Second Restatement §520 (a).

118 Turley, $10 \mathrm{~N}$. Ky. L. Rev. at 43 (cited in note 96 ). Note, however, that only about half of these deaths result from criminal use or accidents; the rest are suicides. See note 1 above. 
they are easily hidden. As demonstrated above, this dangerousness is causally attributable to the activity of manufacture and distribution.

2. Magnitude of harm. The second Restatement factor is the likelihood that the resulting harm will be great. ${ }^{116}$ This factor excludes those activities for which, although the probability of harm may be high, the likely extent of harm is minor. Handguns clearly do not fall within this exception, for the typical harm from them is death or grave physical injury.

In combination, the first two factors isolate those activities that have a high expected cost-that is, frequency times damage-associated with them. With a high-cost activity, it is likely that a reduction in activity levels will lead to a significant reduction in total social cost. Therefore, these two factors give a first approximation of those activities of injurers for which strict liability-compelling reduced levels of the injurer activity-may be preferable to negligence.

3. Ineffectiveness of due care. The third Restatement factor is the inability to eliminate risk by the exercise of due care. ${ }^{117}$ This factor in part seeks to determine whether a negligence standard might be sufficient to control injurer activity levels. But more importantly, it helps define a central attribute of an abnormally dangerous activity: that even in the exercise of due care, there still exists a substantial danger. And indeed, with handguns there is still a high risk of eventual injury even if manufacturers and distributors are entirely nonnegligent.

4. Uncommon usage. The fourth Restatement factor is the extent to which activity is not a matter of common usage. ${ }^{118}$ The inquiry into common usage has been a critical feature of the abnormally dangerous activities doctrine since the inception of the $R y$ lands rule. ${ }^{119}$ It distinguishes those activities that are abnormal in the community.

One justification for this factor is the nonreciprocal nature of the risks imposed by an uncommon activity. ${ }^{120}$ When the enterpriser carries on an unusual activity, he subjects the community to risks of a kind and degree that the community does not in turn

\footnotetext{
${ }^{116}$ Second Restatement § 520(b).

117 Id. § 520(c).

118 Id. $\$ 520(d)$.

118 See notes 35-57 and accompanying text above.

${ }^{120}$ See generally George P. Fletcher, Fairness and Utility in Tort Theory, 85 Harv. L. Rev. 537, 543-56, 569-73 (1972).
} 
impose on the enterpriser. When many in the community participate in the activity, they impose on each other the same kinds and degrees of risks, thus increasing efficiency by assuring that those who engage in the activity will be forced to bear the activity's costs as well.

Perhaps a more important basis for excluding common activities from the abnormally dangerous activities doctrine is that an activity of common usage (e.g., cooking or walking across the street) is less likely to be marginal. ${ }^{121}$ To recall, marginal activity is activity that an actor would not find worth engaging in if he had to bear its full costs, but that he would find worth engaging in under a liability regime that relieved him of the costs of nonnegligent injuries. Unless activity at a given level is marginal, shifting injury costs to the actor will not reduce his activity, and accident costs will not decrease. Conversely, activity of common usage is unlikely to contain a substantial amount of marginal activity, else the loss from the activity (because of the activity's frequency) would be so enormous that it could not be tolerated by a society for enough time to become and remain "common."

In addition, even when a common activity does contain some

121 Landes and Posner have elaborated on this idea in proposing a reverse "infant industries" hypothesis for determining when an activity is abnormally dangerous. See Landes and Posner, $15 \mathrm{Ga}$. L. Rev. at 910-11 (cited in note 113). Their analysis runs as follows: During the early stages of an innovative activity, there is insufficient information to determine whether the activity produces a net social benefit. If forcing the innovator to internalize all the costs of the activity with the strict liability rule does not drive the innovator out of business (i.e. reduce activity levels to zero), it is clear that the activity is producing a net social benefit. At this point the rule of strict liability makes less sense, and negligence should replace it. Id. at 911 . Thus, as an industry matures the hypothesis predicts a movement from strict liability to negligence.

While this hypothesis may cover certain abnormally dangerous activities, activity level analysis demonstrates the merit of the strict liability rule even in mature industries or activities. It is essential not to confuse activities that are mature with activities that are of common usage. The latter, but not the former, implies widespread participation in the activity. An industry that survives a trial period under the strict liability rule and graduates to treatment under the negligence rule has proved that its activity produces a net benefit at some level, but not necessarily at every level. An activity that is not only mature but also widespread has arguably proven more; it may be inferred that the activity produces a net benefit at very high levels. Only in the latter case can one infer that there is little need in terms of social cost to control levels of the activity.

For example, blasting is an especially mature activity, and yet even Landes and Posner admit that because of the relative positions of injurer and victim, blasting is a paradigm case for strict liability. Id. at 909. See also Correa, 605 P.2d at 459. Damage from crashing airplanes is another case that merits application of the rule. Even though airplane transportation is a mature industry, there is absolutely nothing a victim can do to alter activity levels that will reduce the risk of harm from debris that may fall from an airborne plane. Despite the maturity of an industry, then, strict liability still may be the preferred rule. 
marginal activity, it may be impossible through the relatively crude device of liability rules to deter the marginal activity without also deterring much useful activity. Deciding whether or not to act consumes real resources, and if the decision must be made very frequently, the costs of decision making might become excessive.

In determining common usage most courts just state whether an activity "is" or "is not" of such usage, without undertaking any factual inquiry. ${ }^{122}$ The authors of the Second Restatement have given it more thought, ${ }^{123}$ distinguishing, for example, gas and electricity in household pipes and wires, which are of common usage, from large gas storage tanks and high tension power lines, which are not of common usage. ${ }^{124}$ This distinction between the activity of supplying a commodity and that of using that commodity is critical. If courts focus not on the specific risk-creating activity, but instead on the "use" of the products of that activity, all activities in the end can be of common usage. At least one court has already made this error. ${ }^{225}$

The common usage factor in relation to handguns has provoked much discussion in the commentaries. Some of the debate assumes, simplistically, that merely because there are many handguns in society, their manufacture and distribution must be of "common usage." 126 This ignores the fact that despite the widespread proliferation of handguns in society, only a small group of entities participates in the manufacture and original distribution of handguns. ${ }^{127}$ Although a considerable number of entities partici-

${ }_{122}$ See, e.g., Nelms, 442 F.2d at 1168. But see Luthringer, 31 Cal.2d at 500, 190 P.2d at 8 ("[Cyanide gas] may be used commonly by fumigators, but they are relatively few in number and are engaged in a specialized activity. It is not carried on generally by the public, ... nor is its use a common everyday practice. It is not a common usage within the definition.").

123 "An activity is a matter of common usage if it is customarily carried on by the great mass of mankind or by many people in the community. . . . [If] it is not carried on by a large percentage of the population, . . . it is not a matter of common usage." Second Restatement $\S 520$, comment i.

124 Id.

125 "Gasoline is an article in common usage, and the transportation of it in substantial quantities upon the public highways is an essential step in the creation and maintenance of that common usage." Collins v. Liquid Transporters, 262 S.W.2d 382, 382-83 (Ky. 1953). Were this view correct, blasting, which is essential to the creation of homes and buildings that are of common usage, would not be an ultrahazardous or abnormally dangerous activity.

${ }^{126}$ See, for example, Note, 97 Harv. L. Rev, at 1923 (cited in note 88): "In light of the fact that approximately two million handguns are sold each year, the manufacture and sale of handguns are unquestionably of 'common usage." "

${ }^{127}$ See note 6 above. 
pate in the secondary distribution of handguns, ${ }^{128}$ there are probably far fewer players in the handgun distribution game than there are haulers of dangerous substances or contractors who use dynamite. Making and selling handguns is decidedly not a common activity.

5. Inappropriateness of location. The fifth Restatement factor is the inappropriateness of the activity to the place in which it occurs. ${ }^{129}$ This factor derives from the association with land use that the doctrine had during its early development, but it more properly serves the broad function of ensuring that an activity is classified in its context, not in isolation. ${ }^{130}$

The prominence of the locational element in the ultrahazardous cases reflects the fact that nearly all activities are in some way associated with land use, but its purpose is to ensure consideration of all the factors of a particular activity, including its surroundings or circumstances. The main idea is risk assessment: an activity in one situation may not have the same risk features as that same activity in another situation. Focusing on the totality of the circumstances, including the locational aspect, may allow an activity otherwise dangerous to escape the rule; it may also allow an activity harmless at first glance to come within the rule.

In the case of handgun manufacture and distribution, assessing its risks in the light of all the circumstances cuts strongly in favor of classifying it as an abnormally dangerous activity. While the production and distribution processes might not be dangerous in themselves, they look extremely risky when considered in light of the easily foreseeable, harmful uses to be made of handguns. ${ }^{131}$ Thus the superficial argument, made by some courts, that production is not per se dangerous ${ }^{132}$ misses the point of the doctrine.

6. Value of the activity. The final Restatement factor is the particular value the activity has to the community. ${ }^{133}$ The most important purpose of this factor is to exempt activities with large external benefits - that is, benefits realized by people not engaging

228 Id.

129 Second Restatement $\S 520(e)$.

130 Most courts have recognized that analyzing an activity in isolation is inconsistent with the concept of an abnormally dangerous activity. See, e.g., Bridges v. Kentucky Stone Co., 425 N.E.2d 125 (Ind. 1981). Location itself need not be a factor in assessing the context of an activity: "The reasons for imposing absolute liability on those who have created a grave risk of harm . . . are largely independent of considerations of locational appropriateness." Yukon Equip., 585 P.2d at 1211.

131 See notes 96-107 and accompanying text above.

132 See authorities cited at note 79 above.

133 Second Restatement § 520(f). 
in the activity. While strict liability is useful in reducing harmful activity through internalizing social costs, it does nothing to promote activity through internalizing social benefits. Activity with high external social benefits may be reduced below the optimal level even under a negligence regime; imposing strict liability would only exacerbate that problem.

One example of the possible application of the community value exception is when an identifiable region is wholly dependent on the activities of a particular industry. Although the activities of the industry may be relatively dangerous, its business may spin off benefits in employment and wages that (at least in the short run) would exceed the benefits from the same capital, employed in another activity. ${ }^{134}$ In such a community, the bearers of risk (traditionally, such risk would be in the production itself) are likely to be the beneficiaries of the activities that create the risk; hence, a reciprocity of risk may exist, improving the equity of the situation. ${ }^{135}$

The above scenario, however, does not apply to handgun manufacturers. There is little reciprocity of risk with handguns: since the production of handguns is not itself risky, and since handguns flow into the national stream of commerce, the risk of handgun injury is inflicted on the populace in general, and not particularly on the employees of handgun manufacturers. While some handguns such as police revolvers may have external benefits, by and large guns sold to the general public benefit only their owners. ${ }^{136}$ In any case, for most private handguns, external benefits produced are far outweighed by unconsidered external costs, such as fear.

An activity need not satisfy all of the above discussed factors in order to be found abnormally dangerous:

[T] he factors . . . are all to be considered, and are all of importance. Any one of them is not necessarily sufficient of itself ... and ordinarily several of them will be required for strict liability. On the other hand, it is not necessary that each of

134 This observation implies that capital markets are not long-run efficient, a proposition this comment does not endorse; therefore the situation in the text would exist only as a short-run phenomenon.

1s5 This follows from acceptance of the reciprocity theory laid out in Fletcher, 85 Harv. L. Rev. 537 (cited in note 120). For a discussion of Fletcher's theory in the context of ultrahazardous or abnormally dangerous activities, see Charles 0 . Gregory, Harry Kalven, Jr., and Richard A. Epstein, Cases and Materials on Torts 502-03 (3d ed. 1977).

${ }^{238}$ Indeed, police handguns may not even be an example of external benefit, since taxpayers fund their purchase. 
them be present, especially if others weigh heavily. ${ }^{137}$

The true purpose of these factors, then, is to allow a flexible basis for internalizing the external costs of a dangerous activity: "The essential question is whether the risk created is so unusual, either because of its magnitude or because of the circumstances surrounding it, as to justify the imposition of strict liability for the harm that results from it."138

\section{Other Products Distinguished}

Many products initially appear indistinguishable analytically from handguns, in that there is a foreseeable, high risk that they will cause harm. These products include other firearms, knives, alcohol, automobiles, and tobacco. One might wonder whether the manufacturers and distributors of these other products will be liable by analogy if the doctrine of abnormally dangerous activities is applied to the manufacturers and distributors of handguns. ${ }^{139}$ Further analysis, however, demonstrates the unique character of handgun manufacturers and their products.

1. Other firearms. Several factors demonstrate that the application of the abnormally dangerous activities doctrine is much more appropriate for handguns than for other firearms. First, handguns probably create a much greater risk of harm than do other types of firearms. Because of their concealability and easy mobility, handguns are more likely to be used by criminals than are other types of guns; and the basic purpose of handguns is to harm human beings. In contrast, rifles have other primary purposes such as sport and hunting game, which enhance their community value relative to handguns.

Imposing strict liability against the purchasers and users of guns other than handguns will meet with more success than imposing strict liability on the purchasers and users of handguns. Placing liability on handgun purchasers and users is unlikely to be effective, because handgun purchasers and users are often criminals who are unidentifiable or judgment proof. Because of the many lawful uses of other firearms, simple probabilities would indicate that purchasers and users of these firearms are less likely to be criminals, and thus are more readily available to pay the costs of

1s7 Second Restatement $\$ 520$, comment f.

$2 s 3$ Id.

139 This concern is raised in Martin v. Harrington and Richardson, Inc., 743 F.2d 1200, 1204 (7th Cir. 1984), and Perkins v. F.I.E. Corp., 762 F.2d 1250, 1269 (5th Cir. 1985). 
injuries.

2. Other products. As to other products, strict liability against tobacco manufacturers is inappropriate because smokers harm themselves. In the absence of proof of significant involuntary harm to third parties, the relevant analogy is to handgun owners injured by their own guns, a class of handgun victims that should not recover. ${ }^{140}$

Automobiles, alcohol, and knives are somewhat harder cases in that, at least in some situations, they are instrumentalities for uncompensated injuries to third parties. For automobiles, the presence of mandatory insurance in many states reduces the problem of judgment-proof drivers. ${ }^{141}$ Mandatory insurance also reduces injurer activity by raising the effective price of an automobile: the price is not the sticker in the showroom, but rather the sticker plus the present value of liability insurance premiums. Second, the automobile industry is important to the national economy and thus has a high "value to the community," a factor that cuts strongly against finding it to be an abnormally dangerous activity. The value of automobiles certainly far outweighs the harm that can be inflicted through them; unlike many handguns, automobiles are not made with the express purpose of causing harm. It is important to note that most people injured in automobile accidents probably own an automobile. But a victim of a handgun injury is much more likely to be a stranger to the handgun market. Thus, a reciprocity of benefits exists with automobiles that does not exist in the case of handguns.

Knives present a closer analogy to handguns since, like handguns, they are often used as weapons by criminals. The first problem with applying strict liability to manufacturers and distributors of knives is that such activities arguably are of "common usage": practically any knife can become a weapon, and there are a large number of manufacturers and distributors of knives. Second, the risk of harm presented by knives pales in comparison to guns. ${ }^{\mathbf{1 4 2}}$

${ }^{240}$ See notes 144-47 and accompanying text below.

${ }^{141}$ See, e.g., Me. Rev. Stat. Annot., tit. 29, $\$ 782$ (West Supp. 1986) (requiring proof of financial responsibility for those drivers expected to be higher risks); N.J. Stat. Annot. 39:6B-1 (West 1973) (requiring automobile insurance for all registered owners of automobiles in New Jersey).

${ }_{142}$ A recent federal study showed that 10 percent of cases where criminals were armed with knives resulted in stabbings, while only 4 percent of cases where criminals were armed with guns resulted in shootings. The study pointed out the obvious, however: when injuries did occur, the gun injuries were likely to be more severe, and offenders armed with guns were much more likely to complete the crime than those armed with other weapons. See Chicago Tribune $\S 1$, p. 6, col.1 (Jan. 6, 1986). See also Frank Zimring, Is Gun Control 
Finally, the purchase and use of knives for purposes other than injury is so pervasive that the risk of harm attributable to any particular sale is negligible compared to the risk attributable to a particular handgun. Hence, for knives there will be neither a high probability of harm nor a high probability that the harm will be great.

Alcohol is an interesting case because the foreseeability of alcohol-induced accidental and criminal injury is analogous to that for handguns. As with knives, however, the common usage exception comes into play, since manufacturing and selling alcohol are truly ubiquitous activities. In addition, as with knives, the use of alcohol is so widespread and frequent that its beneficial and pleasurable uses-and hence its value-probably far outweigh the harm it causes. Although great in absolute terms, injuries attributable to alcohol, like those for knives and cars, are probably a far smaller percentage of the dollar value of the activity of merchandising these consumer goods than are handgun injuries compared to the value of making and selling handguns.

Imposing liability on alcohol manufacturers and distributors would also be problematic because all alcohol products can create virtually the same dangerous effects on the consumers. Although different alcoholic beverages may taste very different from each other, and may contain higher or lower proportions of alcohol, all can eventually make a person drunk. In this way, one alcohol product is an almost perfect substitute for another; this easy substitution will frustrate any attempt to differentiate the market into lowrisk beverages and high-risk beverages. The only change in activity available is a general reduction in production of all alcoholic drinks. Moreover, in many (if not most) cases it will be extremely difficult in practice to discover which brand of alcohol the injurer had consumed or to implement changes that would make the brands distinguishable.

Finally, the sale of each of the consumer goods discussed above may lack a sufficiently strong causal connection to uncompensated third-party injuries. ${ }^{143}$ It is hard to imagine a general reduction in the production of cars or knives that would save more social costs in third party injuries than would be lost in consumer benefit from everyday purchase and use of these items. Nor do

Likely to Reduce Violent Killings?, 35 U. Chi. L. Rev. 721 (1968) (concluding that even after accounting for the substitution of knives for guns in violent crimes, were guns to be eliminated, the reduction in such crimes would be substantial).

${ }^{143}$ See notes 109-11 and accompanying text above. 
these products seem particularly susceptible to selective marketing or changes in product design that would alleviate costs of injuries to third parties without diminishing their utility in ordinary use. Dangerous knife designs such as switch blades and stilettos are already generally illegal, and manufacturers and distributors of defectively designed automobiles are already strictly liable under products liability doctrine.

In sum, then, the abnormally dangerous activities doctrine is much more appropriate to handgun manufacturers and distributors than to manufacturers and distributors of other consumer items such as cars, alcohol, and knives. A sufficient causal connection probably does not exist between the manufacture and distribution of these items and the harm caused by them. Moreover, they do not meet the requirements of the Second Restatement's totality of the circumstances test. Thus, the proffered analysis of liability for handgun manufacture and distribution produces a carefully limited principle.

\section{E. The Rule in Operation}

1. Who May Sue. The doctrine of abnormally dangerous activities should be applied only when application is consistent with the economic and legal reasoning of the rule. Thus, it is necessary to consider how the rule will operate with different classes of handgun victims.

One class of victims consists of owners of handguns injured by their own guns. For this class, no strict liability action should be available against the manufacturer. A purchaser or user should be made to consider the expected cost of having the gun in her house, and even if a purchaser does not know all the costs of handguns, ${ }^{144}$ it is reasonable to expect purchasers to be sensitive to the expected cost of injuries to themselves. ${ }^{145}$ Denying an action against the

144 See Note, Manufacturers' Strict Liability for Handgun Injuries: An Economic Analysis, 73 Georgetown L. J. 1437, 1454-55 (1985). The gist of the Note is that because (for a variety of reasons) purchasers of handguns will underestimate and ignore handgun injury costs, inefficient purchase decisions result under the negligence rule. The Note argues for adoption of a strict liability rule solely on the basis of economic efficiency-that is, cost internalization-independent of any "legal" basis for the rule. Cost internalization alone, however, may not be a compelling enough reason for adoption of a liability rule.

${ }^{146}$ This assumption of risk should apply to both physical and emotional injuries of the purchaser. For family members injured by the purchased handgun, the purchaser has a prima facie case of loss of consortium. This cause of action, however, should fail even where the purchaser has not acted with contributory negligence, since the purchaser is responsible for the risk that brings about the loss of consortium. But, the victim who has not been contributorily negligent should be free to proceed against the manufacturer. The manufac- 
manufacturer-for example, by the doctrine of assumption of risk as recognized by the Second Restatement-internalizes the costs of the purchasing decision, limiting the potentially costly victim behavior of handgun ownership to its optimal level. Such an exemption from liability is necessary to preserve the benefit of the strict liability rule in maximizing the utility of both victim and manufacturer activity. ${ }^{148}$ However, because family members are not necessarily aware of or responsible for the purchase decisions of another family member, claims for injuries to family members of a gun owner should not be subject to the defense. ${ }^{147}$

Another class of victims consists of strangers to the handgun market. The concern here is with the effect of their conduct on accident frequency and severity. To the extent that strangers are contributorily negligent, they should be barred from recovery against manufacturers and distributors. ${ }^{148}$ But otherwise, these victims merit compensation from manufacturers for their handgun injuries. Admittedly, some conduct of this victim class may be marginal. ${ }^{149}$ But, for the reasons previously discussed, the marginal activity of this class is likely to be significantly less costly than the marginal activity of the manufacturer. ${ }^{130}$

Finally, handgun suicides are another important category of injuries. ${ }^{151}$ In such instances, strict manufacturer liability is most likely to be inefficient, since victim activity is much more signifi-

turer, however, could have a cause of action for indemnification against the purchaser or user of the handgun.

${ }^{146}$ See part I-A above (notes 7-22 and accompanying text).

${ }^{147}$ Similarly, if the presence of the handgun increases the risk that someone else's handgun will injure the purchaser, then liability should remain on the purchaser. For instance, if an armed burglar and a homeowner engage in gunfire in which the homeowner is injured, and it is demonstrated that without the homeowner's gunfire the burglar would not have used the weapon, there should be no recovery against the manufacturer. Presumably, the purchaser bought the gun for just such an occasion, and therefore he ought to insure against the possible costs. Under the theory proposed in this comment, if it is more likely that using a handgun in self-defense will lead to the defender's injury than not, this is strong (but not conclusive) evidence that the defender's conduct was contributorily negligent for purposes of the rule.

${ }^{148}$ For example, walking alone late at night in a crime-ridden neighborhood may qualify in a jury's mind as contributory negligence. However, the jury may decide that it is reasonable to walk anywhere at any time even if it is more costly than it is worth. Note that even though the question of what is an abnormally dangerous activity is one for the court, questions of negligent conduct are for the jury. See Second Restatement $\S 520$, comment 1 .

${ }^{148}$ An example of this may occur when the victim chooses a route for which the risk of handgun injury is greater than that incurred by taking an alternative route.

${ }^{150}$ See notes $24-28$ and accompanying text above.

${ }^{151}$ See Turley, $10 \mathrm{~N}$. Ky. L. Rev. at 42 (cited in note 96) (citing 1979 statistics of approximately 11,000 suicides, half of all handgun deaths). 
cant in creating the social loss than manufacturer activity. Hence, suicides fall into the category of contributory negligence and do not justify compensation within the rule. In sum, then, only injuries from suicides, from bona fide contributory negligence, and to purchasers from their own purchased guns should remain uncompensated.

2. Structure of Suits. Forensic studies are able to identify the handgun responsible for many particular injuries without too much difficulty. ${ }^{152}$ In cases where forensic science cannot identify the make of handgun responsible for an injury, joint and several liability among all handgun manufacturers is a workable solution, since there is only a small group of handgun manufacturers. Under this theory, each manufacturer will attempt to prove that the injuring bullet could not have been fired from one of its handguns. ${ }^{153}$ Defendant manufacturers that cannot eliminate themselves from possible responsibility are available to compensate the victim. Of course, as previously discussed, the manufacturer will then have an action for indemnity against any intervening tortfeasor such as the owner or the user of the handgun.

The distributors of the handgun that caused a particular injury often will be more difficult to identify than the manufacturer. Nor is joint and several liability feasible, since there are so many distributors. Thus, manufacturer liability may have to suffice when distributors cannot be identified.

Estimating the cost of liability will generally fall to insurers as the cost of insuring against this liability becomes a normal business expense. As this expense will no doubt be a significant one for manufacturers and distributors, they will demand a higher price for their goods, with a resultant lower level of production. Some firms may go out of business, and others may eliminate certain products. All will change the way they do business. There is nothing inherently objectionable about this result; it happens naturally in an economy that seeks to eliminate an implicit subsidy.

Making distributors liable as well as manufacturers will allow

${ }^{152}$ See Julian S. Hatcher, Frank J. Jury, and Jac Weller, Firearms Investigation, Identification and Evidence (1957); Jack D. and Charles O. Gunther, The Identification of Firearms (1935).

${ }^{153}$ For example, a manufacturer might make only revolvers, while the bullet was shown to have come from an automatic handgun; or the caliber may be of a size made only by a few manufacturers. More detailed factors, such as the rotation of the rifling or the number of grooves and ridges, may further disqualify certain manufacturers. The rule of joint and several liability gives manufacturers of handguns with low social costs incentives to make bullets fired from their weapons uniquely identifiable. 
these actors to shift liability by contract to the most efficient estimator of risk. ${ }^{154}$ In addition, including the entire chain of distribution in the reach of liability will give each downstream firm an incentive to monitor its supplier for solvency with respect to expected liability claims. Fly-by-night manufacturers will find few distributors willing to deal in their handguns. A legislative response of mandatory insurance (as with taxicab companies) or of minimum capital levels (as with insurance companies) is a further solution to the problem of moral hazard. ${ }^{155}$

3. Retroactivity. One of the important practical considerations of applying strict liability to handgun manufacturers and distributors is whether the rule should apply retroactively to handguns extant at the time the new liability rule takes effect. Manufacturers who sold those handguns presumably did not include in the price the costs they would now be made to bear.

A manufacturer starting production after the new liability rule became effective would, compared to the preexisting manufacturers, gain a significant advantage over preexisting manufacturers in that its capital would not be subjected to risks incurred in previous periods under a different liability regime. Thus the change in liability is too drastic to charge preexisting manufacturers with these risks, despite the fact that such risks were arguably foreseeable. ${ }^{168}$ Thus, in order to limit distributional inequities among owners of manufacturing facilities, and in order to facilitate the transition to strict liability, courts should not impose strict liability retroactively..$^{157}$

164 This comment does not consider whether there should be contribution between manufacturers and distributors. In any case, these actors are likely to work this out by contract.

${ }^{155}$ The risk of moral hazard in firms where the expected liability to tort claimants exceeds capital is not unique to the anticipated structure of the handgun manufacturing industry. Thus, enlisting the aid of the legislature here is simply a general response to a preexisting problem, now identified in a specific industry.

180 The resemblance to asbestos is noteworthy. Had asbestos manufacturers known or even perceived of the ultimate liability, the price of asbestos would have been considerably higher, resulting in decreased use and presumably lower social costs.

${ }^{187}$ This conclusion is consistent with the test for retroactivity set out by the Supreme Court in Chevron Oil Co. v. Huson, 404 U.S. 97, 106-07 (1971). Under Chevron, a court must assess: (1) whether the new decision "establish[ed] a new principle of law, either by overruling clear past precedent. . . or by deciding an issue of first impression whose resolution was not clearly foreshadowed," id. at 106; (2) "'the prior history of the rule in question, its purpose and effect, and whether retroactive operation will further or retard its operation," " id. at 107 (citations omitted); and (3) the respective inequities of retroactive or nonretroactive application, id. Applying the abnormally dangerous activities doctrine to handgun manufacture and distribution (1) establishes a new principle of law, (2) whose purpose would be retarded if applied retroactively, and (3) which would be inequitable if applied to manufacturers who sold guns before the adoption of the rule. Accordingly, strict liability against handgun manufacturers and distributors should not be applied retroactively. 


\section{CoNCLUSION}

The regulation of handguns is an emotional issue, one better suited for the legislatures than for the courts. This comment, however, is not about regulating handguns; it is about making an activity bear its costs. The tort law has an established mechanism for imposing these costs in the doctrine of abnormally dangerous activities, and the doctrine fits the factual situation of the manufacture and distribution of handguns in modern society. The courts ought not to interfere where they have no legitimate role, but neither should they shy away from applying the principles embodied in accepted common law doctrine when legal and economic analyses compel a result.

Andrew O. Smith 